\section{THE WHITE CELLS IN TUBERCULOSIS *}

\section{W. WARNER WATKINS, M.D. • PHOENIX, ARIZ.}

Study of the leukocytes in their relation to disease, or to a particular disense, soon impresses one with the truth of Professor Ehrlich's statement ${ }^{1}$ that the biologic variations of the white cells make them the most interesting study in pathology. Could we definitely know what the changes of the leulsocytes are, at the onset and during the course of a disease, we would have an invaluable aid to the diagnosis and prognosis of that condition. Study of immunity and of the broad field of biologic adaptation in its application to pathology has revealed the white cells as the mobile tissue of the body, the elements most quickly adapting themselves to changes in environment by under'going endless variations in the presence of stimuli furnished by pathologic olganisms and their toxins. Unfortunately, however, for clinical and therapcutic purposes, these variations are, as a rule, so similar in different clisenses and so inconstant in the same infection in different individuals that their diagnostic and prognostic value beconıes somewhat uncertain.

- So far as tuberculosis is concerned, the white cells have been the subject of but limited study, which is rather strange since the reaction of the leukocytes in this wide-spread condition is exceedingly interesting and ought to become a sound basis for practical therapeutics. In America the work of Webb2 is the most Paluable contribution to investigation along this line.

For the sake of clearness this paper ontlines its matter under three divisions:

1. The most important known facts regarding the white cells in tuberculosis.

2. The conclusions growing out of limited and incomplete personal observations.

3. The lines along which further investigation seems to be most needed.

\section{TILE MOST IMPOITANT FACTS CONCEINING TIIE} WHITE CELLS IN TUBERCULOSIS

The biologic law that the nucleus is the dynamic center of living cells and that the cytoplasm is only a means of communication between this center and the surrounding medium, holds true for leukocytes. Then one would naturally conclude that of all the white cells the most powerful ones are those with the largest and most perfect nuclei; this conclusion is justified by the work of several investigators who have proved that the most resistant and, consequently, the most powerful white blood-cells are the large and small lymphocytes. It is interesting, also, in this connection, to note that Ehrlich's assertion that the lymplocytes do not possess ameboid movement and do not respond by chemotaxis to stimuli, has been vigorously disputed by several witers.

In resisting a tuberculous infection it has long been known that the lymphocyte is the cell particularly effective against this bacillus. The term "lymphocyte," as used herein, classes under that word, without any attempt at differentiation, both the small mononuclear leukocyte (the lymphocyte of Ehrlich or small lymphocrte of American writers) and the large mononuclear leulsocyte (the Iarge lymphocyte of American writers),

" Read in the Section on Pathology and Physlology of the Amerlean Medical Association, at the Sixty-Second Annual Session, held Los Angeles, June, 1911 .

1. Elariteh: Anemia.

2. Webb: Hematologle Stuales in Tuberculosis. since no one has yet made any distinction in their function. That these cells are attracted particularly by the tubercle bacilli is doubtful, their effectiveness against these organisms being largely explained through the work of Bergel, confirmed by Webb and his assistants, that only lymphocytes have the ability to dissolve the waxy sheath enclosing tubercle bacilli and protecting them against the destructive antibodies of the serum and against ordinary phagocytes. It is the universal observation of hematologists that there is an increase in the lymphocytes in tuberculosis, but the conclusion lieretofore drawn, that this lymplocytosis is due to seconclary anemia resulting from the disease, is erroneous, for this increase in mononuclear cells occurs only during the process of recovery from, or successful resistance of, tuberculosis, and does not occur when the disease is progressing unfavorably. A fact which simplifies routime observation in this conncction is that when there is an increase in the mononuclears (except in lymphatic leukemia, in which all the elements are increased), this change in percentage is due to an actual relative increase and is not accompanied by a rise in the total leukocyte count.

\section{CONCLUSIONS DRAWN FROM PERSONAL OBSERVATIONG}

Pcrsonal observations have been made from 112 bloorcounts in 100 individuals, with results as follows: Twenty-two healthy adults gave an average lymphocyte count of 41.5 per cent., ranging from 29 per cent. to 57.5 per cent. Thirteen patients definitely cured of tuberculosis of the lungs gave an average lymphocyte count of 45 per cent., ranging from 35 per cent. to 67 per cent. T'wenty-four counts on patients with tuberculosis clsecked or healing gave an average percentage of 38 , ranging from 30 per cent. to 50 per cent. Fortyfour counts from patients in whom the disease was gradually or rapidly progressing gave an average of 25 per cent., ranging from 10 per cent. to 35 per cent. Six who were not seen after the original examination, but whose cases were all advanced, gave an average count of 24 per cent. 'T'wo adults presenting themselves as normals, but whose appearances were suspicious, gave counts of 19 per cent. and 20 per cent. The conclu'sions based on these observations, in view of the established facts concerning lymphocytes in tuberculosis, together with the work of contemporaneous and accurate olsservers, are as follows:

1. 'These observations agree entirely with those of Webb that the percentage of lymphocytes affords an apparently reliable indication of individual resistance to tuberculous infection. A broad classification of patients in whom tuberculosis is still active obscures the important fact-invariably observed in a close analysis of individual patients-that the percentage of lymphocytes. corresponds closely to the condition of the patient and the progress of the disease.

2. There is present in many healthy individuals a considerable increase in the percentage of lymphocytes, so that instead of being 30 per cent., they approximate 40,45 or 50 per cent., or more. These increases are observed particularly in high altitudes and in lowlands where the atmosphere is rarefied by absence of moisture and by high temperature. The conclusion is certainly justified, that an individual presenting such an increase in number of those defensive cells known to be most effective against tubercle bacilli, presents, likewise, an increased resistance against infection by those organ. isms. 
3. There exists in human beings who have definitely recovered from tuberculosis, a permanent increase in the percentage of lymphocytes, the counts ranging from 40 to 70 per cent. That such an increase in those cells known to be particularly destructive to tubercle bacilli aflords a relative jmmunity to tuberculous infection, is a matural conclusion. 'This is a definite biologie confirmation of the much-disputed statement that cured tuberenlosis produces immunity-the degree of the jmmunity being limited only by the definiteness of the recovery.

4. In patients with active tuberculosis, there occurs coincident with, or preceding, the checking of that activity, an increase in the percentage-i. e., the numberof lymphocytes, which continues as long as the lung tissue maintains its resistance and remains permanent if this resistance proceeds to eradication of the tuber' $n$ lous area. This lymphocytosis is so definite and unfailing that it offers the most dependable means that we now have of foretelling from week to week and from month to month what the future course of the disease in those patients will be.

j. On the other hand, preceding by a variable time the lessening of resistance and consequent invasion of new tissue by the bacilli, there ocenrs a decrease in the percentage-i. e., the number-of lymphocytes. This decrease can be observed before any appreciable change in the lungs can be detected, and offers an even mor'e definite and reliable indication of the probable course of the infection in those cases which are so disconcerting in their failure to observe prognoses.

6. The blood of tuberculous patients with lymphocytosis presents, usually, an interesting picture and one very different from that of normal blood. Lymphocytosis is said to depend cliefly on an increase of Nhrlich's large mononuclears-those cells reputed to originate in the bone-marrow. This is true, though these newly formed cells differ in appearance from the ordinary large ovoid lymplocyte. The small lymphocete, forming, ordinarily, about 25 per cent. of the total white cells is, occasionally, the cell which multiplics; but, as a rule, this type of cell becomes subordinate and the mononuclear cells which appear in the blood so rapidly during a tubereulosis in the process of healing may be two or thrce times as large as a polynuclear, and have $a^{\prime}$ large, irregular cytoplasm and a very large, sometimes irregular, nucleus.

7. Actual count of the white cells has not been made in these observations, because the necessity for it was not evident, although, in order to avoid criticism, this should, perhaps, be done. In uncomplicated tubereulosis there is known to be no lettkocytosis, so that an increase in the percentage of one type of cell as slown on a smear preparation, is an actual increase in number of that type. 'The criticism that a mixed infection with pyogenic organisms will bring about an increase in the number of polynuclears and, consequently, a decresse in the percentage of mononuclears without an actual decrease in their number, is a criticism of scientific aceuracy which will have to be answered by checking such invest:gations against actual counts of the lculincytes: The clinical fact remains unaltered, however, that the percentage of lymphocytes is an exact and reliable indication of the course which a tuberculous prosess will assume in the immediate future-whether this percentage is an actual change in number in cases of tuberculosis uncomplicated with pus organisms, or whether it is an apparent change owing to the "preponderance of polynuclears in mixed infections. 1t. LTNES ALONG WIIICH FURTIIER INVESTIGATION IS NEI:DED

In riewing the lines along which further investigit tion is rupeded, the ficld is seen to open up with every new step ard only a few suggestions are offered.

1. The conclusions offered above need to be confinteit by continued investigation, controlled by actual contat; of the vilite cells.

2. Healthy individuals in different scetions of the country should be examined in large numbers to determine, as Webb has been doing, in what sections of the continent there is a tendency to an increase in thos" cells which most effectively resist tubereulosis.

3. The particular methods by which individual resistance against tuberculosis can be raised should be aseertained, with the lymphocyte percentage as an accurate gruide to the degree of such a resistance. In the grent campaign against the white plague, prophylaxis mult eventually be the means of eradicating it, and when suel methods of increasing individual resistance are definitely known, they can be utilized in proplyylactic treatment, whether they are dependent on cliniate, gymmastics of specific immunization.

4. The relationship between the reaction of these cells and the administration of specific agents like tubercitlin, raccines, immune scrums, etc., should be determined; also to what extent the changes in the lympliocyte percertage can be utilized as a guide in specific tratment. One writer makes the statcment that the iymphocytes increase after an injection of tuberculin. If the effect of tuberculin is to stimulate those cells which have the ability to destroy tubercle bacilli, there must be a close connection between that effect and the increase in lymphocytes. If the cffect of tuberculin and allicel remedies is to catuse the production of antibedies in the blood-serum, lymphocytes being known to participate in the production of such bodies, it is erjdent that there are relations of cause and eftect not $y^{\mathrm{et}}$ discorered.

5. The trend of study and investigation in tuberctlosis is toward the blood-blood-sermm and blood-cellsand the more these are studied, the clearer is the conviction the world over, that Koch, in his discovery of the hacillus and of tuberculin, did not, by any means reach the summit of valuable knowledge in this discase.

23 East Adams Street.

\section{ABSTRACT OF DISCUSSION}

Dr. Gerald B. Wend, Colorado Springs: Dr. Watkins' excellent paper corroborates our former work. When we disen ered the increase of lymphocytes in Colorado Springs wh considered it due to the same marrow hyperplasia which causes the increase of the red corpuscles. Professor Zunt las recently written me that he considers these changes dive most probably to lack of oxygen in the bone murrow. of lave been able to produco the same results by hyperemia of the marrow, increasing the lympliocytes by 100 per cent.

Dr. Watkins spoke of the differential blood-counts found at the Salton Sea. I would like to ask our Chairman (Dr. Hell derson) if he could explain the possible hyperplasia of tha marrow in this region by reason of stimulation duc to exce $\mathrm{g}^{\mathrm{g}}$ of earbon dioxid retained in the blood.

Dr. Yandell Henderson, New Tiaven, Comn.: I con $\mathrm{f}^{\mathrm{g}^{\mathrm{g}}}$ that I cnnnot give any explanation of the effect of the Salton in Sea. There have been extensive investigations recently in (iermany on the effects of sen buths and seashore climates' but so far as $I$ am aequainted with them they do not off any ground for an answer to the question.

Dis. J. J. Portingen, Monrovia, Cal.: The attempt to determine the variation in leukocytes at diflerent altitude 
is a good one, as no doubt there is considerable physiologic variation. My work has been done at an elevation of 1,000 feet. I have made about 800 differential counts on some 600 patients. I have not been sufficiently impressed with any particular variation from the normal in lymphocyte percentage to attempt to establish a rule, aside from the incrensed percentage in the early stages of the disease and a decrease, often, in serious eases. From the data presented by Dr. Watkins the question naturally arises as to what the value of altitude might be in establishing immunity. Sufficient work has already been done to show that the lymphocyte is probably more active in increasing the resistance of the individual in tuberculous disease than we lad formerly supposed, but since this same increase in lymphocytes is to be seen in normal people at an altitude, we are obliged to consider that such inerease in diseased persons must be in part physiologic and cannot be considered as a favorable reaction against the disense process.

$A_{B}$ the technic employed in making counts is very impor. tant, I wish to ask Dr. Watkins what teclnic was employed in making his computations.

DR. W. W. Watrins, Ploenix, Ariz: I will say, first, that my chief object in presenting this papdr was that I thought the criticisms which would be offered would be of value to me in future work along the same line. As to the criticism regarding conclusions based on only 100 patients, of course, conclusions of value cannot be drawn from 100 examinations, in any condition, if that were all; but as there were thous. ands of cases reported in liternture, I felt justified in drawing conclusions which simply confirmed the work of other men.

As to the technic of the smears, I used both the method recommended by Whrlieh with rover-slips and the method recommended by DaCosta with slides. The one I chiefly used is that of taking the ordinary slide, properly cleaned and prepared, putting on tlie drop of blood, bringing the end of another slide up to the drop and then pulling it away, the blood following the slicle. In these smears, the drop was kept in the central portion of the slide. I take three or four, never less than two. The smenrs, when the leukocytes are bunched at the terminus of the smear, camnot be depended on. The leukocytes must be distributed evenly throughout the smear to be of value. The stain used was Wright's.

\section{PROLAPSE OF THE U'IERUS COMPLICA'TING PREGNANCY *}

PAIMER FINDLEY, M.D.

Professor of Gynecology, College of Medicine, State University of Nebriska OMAIIA

Of the malpositions of the uterus, descensus is most often encountered. This applies as well to the early pregnant uterus in descensus of moderate degree. It is well known that a moderate degree of descensus uteri is not incompatible with pregnancy and with normal delivery, but complete prolapse of the gravid uterus is rarely seen and has never been observed at full term. A number of cuses have been so recorded, but it is belicved that in these cases the edematous, elongated cervix and inverted vaginal walls have been mistaken for the uterus in its entirety (Braun-Fernwald ${ }^{1}$ ). In Plasse's case the patient went to the seventh month of gestation. No other reported case has developed to this degree. In this instance the fetus was macerated.

The first noteworthy contribution to the subject was by Hüter ${ }^{2}$ in 1860 ; the next by Franke, ${ }^{3}$ who brought the total of reported cases to 124 . Scitz followed with * Read In the Section on Obstetiles and (iynecology of the
Ampicican Medical Assoclation, at the Slxty-Second Annual Session, held at Ios Angeles. Iune. 1911.

1. Braun-Fernwald: Winckel, Handbuch der Geburtsh., 11.

2. Hiter: Monatsclar. f. Geburtsk. u. Frauenkr., Beri., 1800,

3. Franke : In 1 ugural 'Thesis, Jena, 1802.

4. Seitz: Belti. z. Geburtsk. u. Gynikk., 1902, vi, 250. a noteworthy contribution on the subject published in 1002.

With the aid of Dr. Heaney of Chicago I have collected, in all, 140 cases in the literature to which I will add one of my own and two as yet unreported cases.

We seldom find prolapsus of the gravid uterus in a primipara. The displacement is usually the result of pregnancy, lience a condition common to multiparx. As to the time of occurrence, we find in the majority of case-records that the procidentia was not manifest until one or more children were born; that there had preexisted a descensus of the uterus to a greater or lesser degree, and that the descensus had increased in the subsequent pregnancy. In other words prolapsus uteri in pregnancy is but an exaggeration of a preexisting condition.

Tracon ${ }^{6}$ reported two cases in which the prolapse occurred cluring pregnancy, one in the fourth montl due to a severe strain and the other when at stool. Stamm ${ }^{\circ}$ also reported two cases, and Verre, Webb and liosano rach a case in which the prolapse occurred in pregnancy,

In the case reported by Kidd, ${ }^{7}$ the prolapsus was first in evidence at the time of labor, though in his case the woman had given birth to three children and had had five abortions, making it probable that the uterine supports had been weakened prior to the last labor in which the prolapse occurred.

Dufour $^{8}$ records a case in which the pregnant uterus was prolapsed to the level of the linees. 'The woman had borne three children and was in the sixth month of gestation. The cervix protruded from the vulva throughout the six months of pregnancy. With the first pain incident to premature labor, the membranes ruptured and the entije gravid uterus protruded to the level of the knees. The protruding uterus and vaginal walls became deeply congested and for fear of gangrene the uterus was promptly emptied by first incising the cervix. Boissard ${ }^{0}$ recorded a similar experience in a pregnancy of three months. Wagner, ${ }^{10}$ Harvey and Plasse also reported cases in which the gravid nterus hung to the knees. The first case of acute prolapsus occurring in labor was reported by Mauriceau. Similar cases have been reported by Gristock, Kauffman, Wagner, Stein, Poetal, Meralini, Chemin, Smelli, etc.

The likelihood of pregnancy occurring in a prolapsed nterus is in inverse ratio to the length of the cervix, the degree of prolapsus of the uterus and vaginal walls and to the tissue changes resident in the uterus and its appendages. Where the cervix protrudes from the vulvar outlet, pregnancy will rarely supervene. In prolapsus of long standing the usual anatomic findings are eversion and erosion of the lips of the cervix, hypertrophy of the enclometrium and uterine musculature and cystic degeneration of the ovaries. Such a combination of lesions, irrespective of the position of the uterus, will greatly lessen the chances of pregnancy. Add to these lesions the possible fixation of the uterus and its appendages by pelvic adhesions and the chances of pregnancy are almost nil, with practically no chance of maturing the pregnancy. Winckel reported two cases in which the anterior lip of the cervix attained the size of a man's fist and caused ischurin. The swelling of the anterior lips of the cervix has been observed in a number of cases

\footnotetext{
5. Tracon : Arch. de tocol., 1891, xvil.

6. Stamm : Julss. WVllabur., 1898.

7. Kldd, lF. : Cent ralbl. f. Gynkk., 1800, No. 35, p. 627

8. Dufour: Monatschr. f. Geburtsh. xvi.

8. Bolssard : Nonv. Ann. clin. de Montpeller.

10. Wagner: Martin, Atlas, 'I'ab. 47 , Flgure 5 .
} 